\title{
Protein Utilization, Immune Function, and Hepatic Antioxidant Activity of Rats Fed Tahini in Combination with Other Oily Seeds
}

\author{
Ghiath Sumainah ${ }^{1}$, Louay Laban ${ }^{2 *}$ \\ ${ }^{1}$ Department of Biological Science, Syrian Private University, Damascus, Syria; ${ }^{2}$ Department of Nutrition, Al Rashed Private University, \\ Damascus, Syria
}

\begin{abstract}
Aims and objectives: Consumption of sesame seed products is increasing worldwide, and sesame may be suitable as a quality protein source for preschool children when combined with other sources of plant proteins. Sesame paste, or Tahini, is a traditional food in countries of the Middle-East, where other seed proteins such as the chickpea, soybean, and peanut are also locally available. Although the protein in sesame is low in lysine, but it's rich in sulfurcontaining amino acids in comparison to other seed proteins. Additionally, sesame contains potent water and fat soluble antioxidants with may affect immune function.
\end{abstract}

Materials and methods: In this study, the growth response, liver antioxidant activities were measured. And in vivo cell-mediated immune function in hamsters fed rations in which the protein content was $10 \%$ and was either all from Sesame Paste (SP), one-fourth from sesame paste and three-fourths from chickpea (SC), or one-half from sesame paste and one-fourth each from Soybean and Peanut (SSP). There were 2 control rations, both containing casein as the protein source and fat from either soybean oil or sesame oil. Total fat content of the rations was similar. Syrian male hamsters were fed ad libitum for 4 weeks, after which they were administered a Delayed-Type-Hypersensitivity (DTH) test of were assessed for liver antioxidant activity using $a \alpha$ - diphenyl-b-picrylhydrazyl.

Results: Protein utilization, as measured by the standardized PER, was 2.50 or both control groups, 1.08 for group S, 1.59 for group SSP, and 2.18 for group SC. Liver tissue antioxidant activity was significantly higher in all 3 groups containing sesame paste vs. the control groups. The DTH response was similar among the control groups and rate fed rations SC and SSP, but significantly greater in rats consuming the S ration. In summary, the SC formula containing protein that was $25 \%$ from sesame paste and $75 \%$ from chickpea is of good quality, supported normal cell-mediated immune function, and raised hepatic antioxidant level in comparison to the casein controls.

Conclusion: Sesame seeds products such as Tahini can play an important role as antioxidants especially for the hepatic functions.

Keywords: Sesame; Tahini; Immune function; Chickpea; Protein utilization; Liver antioxidantssors

\section{INTRODUCTION}

In various parts of the world efforts are being made to increase the consumption of vegetable protein from locally available sources. Sesame paste (Tahini) has a reputation as a popular food in EastAsia and in Middle-East countries [1]. It is made from ground, dehulled, dry-roasted sesame seed (Sesamun indicum L). The high oil content of approximately $60 \%$ consists mostly of oleic (39\%) and linoleic (40\%) acids [2]. Sesame paste also contains relatively high protein content $(26 \%)$ and a low percentage of crude fiber and moisture [3].
The oil in sesame is remarkably stable and resistant to oxidative deterioration due to indigenous fat and non-fat antioxidants (tocopherols and lignans) [4-6]. Many of these antioxidants exist as the glucosides of sesamol, sesamin, sesaminol, sesamolinol, and pinoresinol [7]. There is evidence that the glucosides act as potent in vivo antioxidant substances $[4,8]$. In addition, they are capable of altering prostaglandin synthesis, thereby potentially affecting immune function [9]. Thus, increasing the rationary intake of sesame may improve health status. However, sesame use, especially for the preschool child, is hampered by the poor quality of its protein. Sesame is very low in lysine. Yet, the protein

Correspondence to: Louay Laban, Department of Nutrition, Al Rashed Private University, Damascus, Syria, E-mail address: drlouay@yahoo.com

Received: March 22, 2021; Accepted: April 18, 2021; Published: May 04, 2021

Citation: : Sumainah G, Laban L (2021) Protein Utilization, Immune Function, and Hepatic Antioxidant Activity of Rats Fed Tahini in Combination with Other Oily Seeds J Food Process Technol 12:895

Copyright: ( 2021 Laban L, et al. This is an open-access article distributed under the terms of the Creative Commons Attribution License, which permits unrestricted use, distribution, and reproduction in any medium, provided the original author and source are credited. 
is exceptionally rich in sulfur-containing amino acids, whereas these building blocks are present at low levels in most other seed proteins [3]. Complementing sesame protein with other sources of seed protein has been shown to enhance overall protein quality $[10,11]$. Chickpea, peanut, and soybean are good complementary foods due to their widespread availability in the Middle-East and Asian countries.

The purpose of our study was to evaluate sesame seeds in combination with chickpea, peanut, and soybean, as a means to significantly raise the protein quality and to possibly demonstrate its antioxidant and immune stimulating properties in the rat.

\section{MATERIALS AND METHODS}

Processing of seeds: Sesame paste (Tahini), the standard commercial made from Sesamum indicum Linn, was purchased through a supplier in $20 \mathrm{~kg}$ plastic buckets from Lebanon (Al-Kanater Factory, Beirut). It was kept under refrigeration until used. A protein of the paste was partially defatted by repeated centrifugation (4000 g) until no further oil would separate.

Raw chickpea (Cicero arietinurn Linn) was supplied from a commercial source, raw soybean seeds and heat-treated peanuts were obtained from the Department of Agronomy at the University of Damascus. The chickpea and soybean seeds were soaked with water $(3: 1)$ for 18 hours and then drained. Soaked soy was boiled in $0.5 \% \mathrm{Na}$ bicarbonate for 45 minutes to inactivate the antinutritional factors.
Chickpea was autoclaved at $121^{\circ} \mathrm{C}$ for $45 \mathrm{~min}$. Excess water was eliminated and the seeds were air-dried, freeze-dried, and then ground to pass $1 \mathrm{~mm}$ mesh. The proximate analysis is presented in table 1.

Ration treatments (Table 2): All rations were formulated in the laboratory prior to the launch of the study and they were mixed in a Hobart mixer and fed in powdered from. There were two control rations, namely $\mathrm{CON}$, made with casein with soy oil, and CS, containing casein and sesame oil. The groups were sesame pastechickpea (SC) (protein source 25\%, 75\% respectively). Sesame paste alone (S) (protein source 100\%), and sesame paste-peanut-soy (SSP) (protein source 50\%, 25\%). All rations were formulated to give $10 \%$ total fat and $10 \%$ crude protein.

\section{PER}

60 Syrian or golden Hamster Males (Mesocricetus auratus) (weighing $41 \mathrm{~g} \pm 1 \mathrm{~g}$ ) were purchased from the local laboratory animal breeding establishment (Damascus, Syria). These animals were acclimated to the laboratory for 3 days before initiating the experiment. All procedures for laboratory animals were in accordance with approval of the Institutional Animal Welfare Committee of the Syrian Private University. The Syrian hamsters were housed individually in stainless steel cages with $12-\mathrm{Hr}$ light/dark cycle. They were randomly assigned into five groups $(n=12)$, and given water and food ad libitum. Their body weights and food intakes were recorded

Table 1: Proximate Analysis of the Protein Sources.

\begin{tabular}{cccccc}
\hline \multirow{2}{*}{ Ingredients } & \multicolumn{5}{c}{ Constituents as Percent } \\
\cline { 2 - 6 } & Moisture & Protein $^{1}$ & Fat & T-CHO & Ash \\
\hline Sesame paste, non-defatted & 2.81 & 20.6 & 57.1 & 16.68 & 2.81 \\
\hline Sesame paste, partially defatted & 3.4 & 33.31 & 35.1 & 23.78 & 4.41 \\
\hline Chickpea & 2.05 & 25.8 & 6.21 & 62.92 & 3.02 \\
\hline Soybean & 2.02 & 38.82 & 20.01 & 35.93 & 3.22 \\
\hline Peanut & 2.03 & 25.5 & 44.41 & 26.07 & 2.3 \\
\hline Casein ANRC & 6.71 & 89.82 & 0.31 & 0.84 & 2.32 \\
\hline
\end{tabular}

${ }^{1}$ Nitrogen to protein conversion factors are from USDA Handbook no.8 (Casein 6.38\% Peanut 5.46\% Soybean 5.11\% Chickpea 6.25\%)

${ }^{2}$ Total carbohydrate calculated by difference between the sum of the weight of crude protein, total fat, moisture, ash, and the total weight of the food.

Table 2: Compositions of the rations.

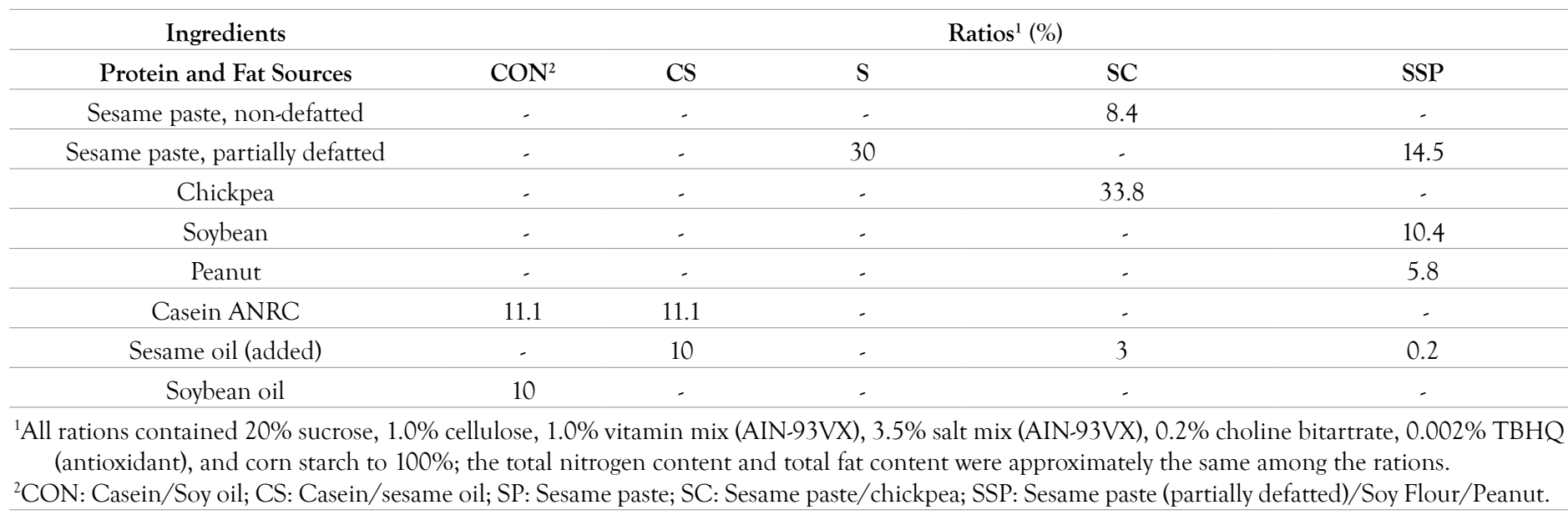


weekly for four weeks. Spilled food was collected and accounted for in tabulating weekly food intake.

PERs were calculated according to AOAC [12]. All values were then standardized to the CON group set to 2.50.

\section{Cell-mediated immune function assay}

At the end of the PER assay 7 animals from each group were subjected to an in vivo Delayed-Type Hypersensitivity Reaction (DTH) assay procedure as follows [13-15]. On day 1, the rats were anesthetized with Ketamine ( $80 \mathrm{mg} / \mathrm{kg}$ body weight), shaved over the abdomen, and painted with $100 \mu$ of $1 \%$ DNFB (Dinitroflourobenzene) in 4:1 acetone: olive oil. On the second day, another application of DNFB on the abdomen was made without anesthesia. On day 4, one ear was challenged with $50 \mu$ of $0.5 \%$ DNFB in the vehicle. The other ear was painted with the vehicle to serve as the non stimulated control ear. After 24 hours, ear thickness (swelling) was measured with a precision micrometer. The level of DTH response was quantified by the difference of ear swelling between the stimulated and non-stimulated ears in the same animal, expressed as the ratio of thickness of treated over untreated ear. A greater degree of swelling of the treated ear is indicative of a stronger immune response.

Antioxidant activity: The remaining five hamsters of each group were anesthetized. The liver was harvested, weighed and frozen pending analysis. Liver tissue was also collected and analyzed from the rats were subjected to the DTH test above. Antioxidant activity was measured by the Glavind method using $\alpha, \alpha$ - DipheylPicrylhydrazyl (DPPH) [16,17].

All data were subject to Analysis of Variance (ANOVA) using SAS, version 6.12 (SAS Institute, Cary, North Carolina). Duncan's multiple range tests were used to detect differences among treatment means if the F-value was significant. All effects were considered significant at $\mathrm{P}<0.05$.

\section{RESULTS AND DISCUSSION}

Protein Utilization Standardized (Tables 3 and 4): Food intake and weight gain over the 4-week feeding study was highest for the Casein Soy Oil (CON) Control group. The Casein Sesame (CS) oil control group showed slightly lower food intake and weight gain but had the same PER as the CON rats.

In the group on the Sesame Chickpea (SC) ration, food intake was $3 \%$ less than the CON group but weight gain was 23\% lower, the
PER value of 2.18 was $13 \%$ less than the CON group Rats on the Sesame Soy Peanut (SSP) ration had significantly less food intake and weight gain than the CON group; the PER was only 1.59 . Lastly, rats consuming the ration containing Sesame (S) as the only protein source showed a markedly low food intake and a weight gain of only about $4 \mathrm{~g}$ per week; the PER of 1.08 was significantly lower than all other rations treatments.

Calculations of the Amino Acid Score as well as the Protein Digestibility Corrected Amino Acid Score (PDCAAS) using the FAO/WHO reference values for the pre-school child are compared to evaluate the quality of a protein for humans [18]. Digestibility factors for the seed proteins are $85 \%$ for sesame, $88 \%$ for chickpea, and $95 \%$ for both peanut and soy [18]. For the ration containing sesame as the sole protein source (S), the low lysine score of 0.56 and the PDCAAS of only 48 is consistent with its low PER of 1.08. The combination supplying $25 \%$ sesame protein plus $75 \%$ chickpea protein (SC) increased the lysine score to almost unity while maintaining the ratios of all other essential amino acids at or well above 1.0. The PDCAAS rose markedly to 83, which was reflected by a doubling of the PER. Enriching sesame protein with Soybean and Peanut (SSP) improved the lysine score to 0.73 and the PDCAAS to 64 , but these changes failed to raise the PER above 2. Any further dilution of the sesame protein with soybean and/or peanut would theoretically compromise the threonine ratio and thus the PDCAAS and PER. In general, a PER value below 1.5 indicates a protein of low quality, between 1.5 and 2.0 of intermediate quality, and above 2.0 as good quality [19]. Thus the SC ration would be classified as a good quality protein source.

Hepatic Antioxidant Activity: Among the major body organs, the liver is known to contain the highest concentration of antioxidant substances [15]. In our study, the two control groups showed almost identical antioxidant activity of the liver. Thus, the sesame oil added to a Casein Sesame (CS) did not enhance antioxidant activity in the liver compared to the casein ration containing soybean oil as the fat source $(\mathrm{CON})$. In all three rations treatments which contained sesame paste, the liver antioxidant activity significantly. The SC group showed 33\% higher activity compared with the controls, while the S and SSP groups were up by $64 \%$ and $76 \%$, respectively. Kang et al., [20] recently reported that the addition of 10 defatted sesame flour led to a significant reduction in oxidative stress as measured by lipid peroxidation of hepatic tissue in rabbits. It is evident that even a ration containing only $25 \%$ of the total protein as sesame was of significant benefit to hepatic antioxidant capacity. Moreover, rations containing at least $50 \%$ of the protein as sesame

Table 3: Efficacy of protein utilization of rations containing sesame paste or combinations of sesame paste with chickpea, soy, and peanut.

\begin{tabular}{|c|c|c|c|c|}
\hline \multirow{2}{*}{ Ration $^{1}$} & Protein & Food intake & \multirow{2}{*}{ Body weight gain $(\mathrm{g} / 28 \mathrm{~d})$} & \multirow{2}{*}{$\mathrm{PER}^{2}$} \\
\hline & $(\mathrm{g} / 100 \mathrm{~g})$ & $(\mathrm{g} / 28 \mathrm{~d})$ & & \\
\hline $\mathrm{CON}$ & 11.33 & $383^{\mathrm{ab}} \pm 3^{3}$ & $119^{a} \pm 6$ & $2.50^{\mathrm{a}} \pm 0.06$ \\
\hline $\mathrm{CS}$ & 10.63 & $369^{\mathrm{ab}} \pm 7$ & $107^{\mathrm{b}} \pm 3$ & $2.50^{\mathrm{a}} \pm 0.05$ \\
\hline $\mathrm{S}$ & 10.69 & $235^{\mathrm{e}} \pm 12$ & $29^{c} \pm 1$ & $1.08^{d} \pm 0.04$ \\
\hline $\mathrm{SC}$ & 10.38 & $373^{\mathrm{ab}} \pm 10$ & $92^{e} \pm 2$ & $2.18^{b} \pm 0.05$ \\
\hline SSP & 11.56 & $347^{\mathrm{b}} \pm 2$ & $70^{d} \pm 2$ & $1.59^{c} \pm 0.03$ \\
\hline
\end{tabular}

${ }^{1}$ CON: Casein/Soy Oil; CS: Casein/Sesame Oil; S: Sesame Paste; SC: Sesame Paste/Chickpea; SSP: Sesame Paste (partially defatted) / Soy Flour/ Peanut.

${ }^{2}$ PER's were standardized to CON 2.50.

${ }^{3}$ Mean \pm SEM; Means with unlike superscript letters in the same column are significantly different $(\mathrm{p}<0.05) ; \mathrm{n}=12$. 
Table 4: Protein Digestibility Corrected Amino Acid Score (PDCAAS) using the pre-school child's amino acid requirements as reference.

\begin{tabular}{|c|c|c|c|c|c|c|c|c|c|c|}
\hline \multirow{2}{*}{ Ration $^{1}$} & \multicolumn{8}{|c|}{ Amino Acid Score } & \multirow{2}{*}{ PDCAAS } & \multirow{2}{*}{ Rat PER $^{2}$} \\
\hline & Lys & SAA & Thr & Trp & Val & IIe & Leu & Phe \& Tyr & & \\
\hline $\mathrm{CON}$ and $\mathrm{CS}$ & 1.45 & 1.36 & 1.35 & 1.18 & 1.86 & 1.96 & 1.48 & 1.78 & 100 & 2.5 \\
\hline $\mathrm{S}$ & 0.56 & 2.14 & 1.22 & 1.95 & 1.6 & 1.54 & 1.16 & 1.51 & 48 & 1.08 \\
\hline $\mathrm{SC}$ & 0.95 & 1.13 & 1.13 & 1.15 & 1.3 & 1.53 & 1.1 & 1.43 & 83 & 2.18 \\
\hline SSP & 0.73 & 1.57 & 1.02 & 1.49 & 1.5 & 1.5 & 1.14 & 1.39 & 64 & 1.59 \\
\hline
\end{tabular}

${ }^{1}$ CON: Casein/Soy Oil; CS: Casein/Sesame Oil; S: Sesame Paste; SC: Sesame Paste/Chickpea; SSP: Sesame Paste (partially defatted)/Soy Flour/ Peanut.

${ }^{2}$ PER's were standardized to casein value of 2.50 .

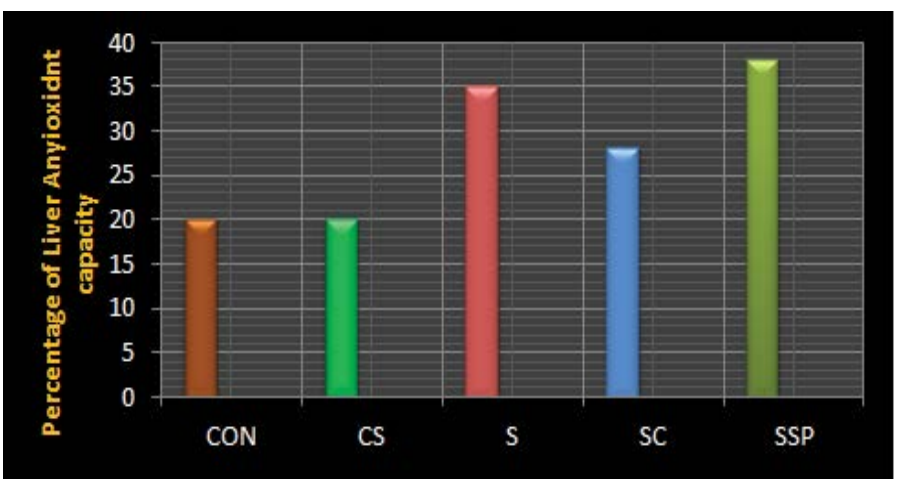

Figure 1: Liver antioxidant capacity in rats fed rations contains sesame paste or combinations of sesame paste with chickpea, soy, and peanut.

(SSP and S) resulted in further statistically significant increases in antioxidant activity (Figure 1).

In vivo cell-mediated immunity (delayed-type hypersensitivity): In comparison to the CON group, rats on rations SC, SSP, or the control ration containing Sesame Oil (CS) all showed similar responses to the DNFB immune function assay. This indicates that rations with these plant protein combinations or a casein ration with sesame oil as the only fat source were effective at promoting a normal immune response to a challenge, and that this response was unrelated to PER values. The group on the ration containing only Sesame Paste (SP) as the protein source demonstrated significantly stronger immune function compared with all other groups. The explanation for this finding may be related to the moderate level of malnutrition by rats in this group as a consequence of their markedly low food intake and weight gain.

Whereas severe malnutrition leads to depressed immunity, moderate malnutrition or undernutrition is known to improve the cellular immune response [21,22]. The voluntary food intake of rats in the $S$ group was approximately one-third lower than the other groups while weight gain was less than one-half of any other group. This response was most likely due to the low lysine content of sesame protein, which led to a degree of undernutrition sufficient to alter immune function. In the two other groups that consumed rations containing sesame in combination with other seed proteins (groups SC and SSP) food intake and weight gain were affected to a much lesser extent, resulting in only a very mild state of undernutrition. This was apparently insufficient to alter immune function compared with the control groups.

\section{CONCLUSION}

In summary, the $\mathrm{SC}$ formulation containing protein in a ratio of 1

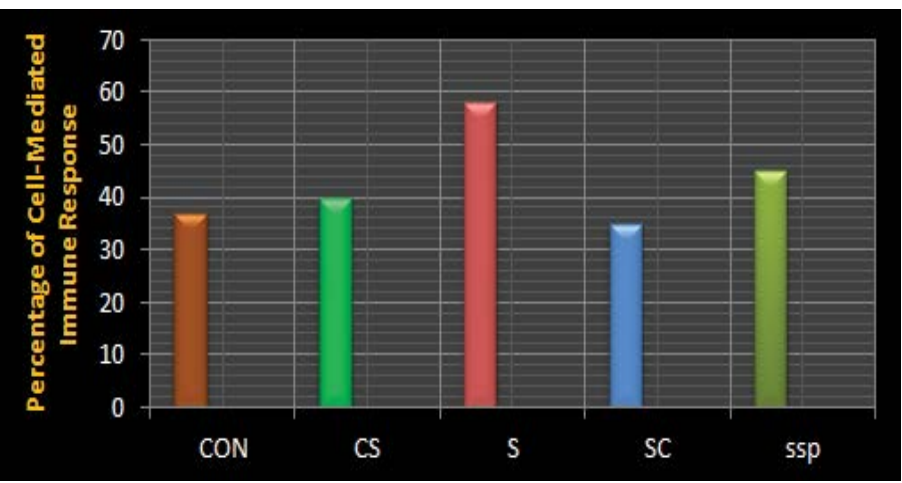

Figure 2: In Vivo cell-mediated immune response as measured by dnfb assay in rats fed rations containing sesame paste of combination of sesame paste with chickpea, soy, and peanut.

part sesame to 3 parts chickpea resulted in an amino acid pattern that met $95 \%$ of the lysine needs and at least $10 \%$ of all other essential amino acids as recommended for the pre-school child. The comparatively high PER confirmed the favorable nutritive value of this protein combination. In addition, this sesame-chickpea combination enhanced liver antioxidant activity and supported a normal response to a cell-mediated immune test in comparison to an isonitrogenous casein-based ration.

\section{CONFLICT OF INTEREST}

The authors declare no conflicts of interest.

\section{REFERENCES}

1. Johnson LA, Suleiman TM, Lusas EW. Sesame protein: A review and prospectus. J AM Oil. Chem Soc 1979;56:463-8.

2. Joint FA. Dietary fats and oils in human nutrition. Report of an Expert Consultation, Rome. 1977:21-30

3. Posati LP, Orr ML. Composition of Foods-Dairy and Egg Products: Raw, Processed, Prepared. Agri Res Service, US Department of Agri. 1976.

4. Fukuda Y, Toshihiko O, Namiki M, Ozaki T. Studies on antioxidative substances in sesame seed. Agric Biol Chem. 1985;49:301-306.

5. Fukuda Y, Nagata M, Osawa T, Namiki M. Chemical aspects of the antioxidative activity of roasted sesame seed oil, and the effect of using the oil for frying. Agric Biol Chem.1986;50(4):857-62

6. Majdalawieh AF, Dalibalta S, Yousef SM. Effects of sesamin on fatty acid and cholesterol metabolism, macrophage cholesterol 
homeostasis and serum lipid profile: A comprehensive review. Eur J Pharmacol. 2020;1:173417.

7. Namiki M. The chemistry and physiological functions of sesame. Food Rev Internat 1995;11(2):281-329.

8. Kang $\mathrm{MH}$, Naito M, Tsujihara N, Osawa T. Sesamolin inhibits lipid peroxidation in rat liver and kidney. J Nut. 1998; 128(6):1018-22.

9. Utsunomiya T, Chavali SR, Zhong WW, Forse RA. Effects of sesamin-supplemented dietary fat emulsions on the ex vivo production of lipopolysaccharide-induced prostanoids and tumor necrosis factor $\alpha$ in rats. Am J Clin Nut. 2000;72(3): 804-8.

10. Guggenhein K, Szmelchan S. Protein-rich mixture based on vegetable foods available in Middle Eastern countries. J Agic Food Chem.1965;13:148-151.

11. Matoth Y, Elian E, Gruenberg E. Evaluation of a protein-rich mixture based on vegetable foods of Middle Eastern countries. Am J Clin Nutr. 1968;21:226-229

12. AOAC Protein efficiency ratio, rat bioassay, method 960.48. In:Official methods of analysis of the association of official Analysis Chemists. 1990:1095-1098.

13. Phanuphak P, Moorhead JW, Claman HN. Tolerance and contact sensitivity to DNFB in mice: I. In vivo detection by ear swelling and correlation with in vitro cell stimulation. J Immunol. 1974;112(1):115-23.
14. Parker D, Long PV, Turk JL. A comparison of the conjugation of DNTB other dinitrobenzenes with free protein radicals and their ability to sensitize or tolerize. J Invest Dermatol. 1983;81:198-201.

15. Cho GY, Hough W. Time course of contact hypersensitivity to DNFB and histology findings in mice. J Korean Med sci. 1986;1:31-36.

16. Glavind J. Antioxidants in animal tissue. Acta Chem Scand 1963;17:1635-1640.

17. Fauconneau B, Waffo Teguo P, Huguet F, Barries L, Decendit A, Merillon JM. Comparative study of radical scavenger and antioxidant properties of phenolic compounds from Vitis Vinifera cell cultures using in vitro tests. Life Sci. 1997;61:2103. 2110.

18. FAO/WHO. Protein Quality Evaluation. Report of a joint FAO/WHO expert consultation. Food and Agriculture Organization of the United Nations. Rome, Italy. 1991.

19. Friedman M. Nutritional value of proteins from different food sources. A review. J Agric Food Chem. 1996; 44: 6-26.

20. Kang MH, Kawai Y, Naito M, Osawa T. Rationary defatted sesame flour decreases susceptibility to oxidative stress in hypercholesterolemic rabbits. J Nutr. 1999;129:1885-1890

21. Parratt D. Nutrition and immunity. Proc Nutr Sod. 980;39:133140.

22. Good RA, Lorenz E. Nutrition and cellular immunity. Int J Immunopharmacol.1992;14:361-366. 